DOI: https://doi.org/10.47405/mjssh.v6i2.661

\begin{tabular}{|c|c|}
\hline 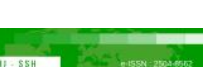 & Malaysian Journal of Social Sciences and Humanities (MJSSH) \\
\hline Malaysian Journal of & Volume 6, Issue 2, February 2021 \\
\hline (Mu-ssH) & e-ISSN : 2504-8562 \\
\hline & $\begin{array}{l}\text { Journal home page: } \\
\text { www.msocialsciences.com }\end{array}$ \\
\hline
\end{tabular}

\title{
Impact of Technology Progress on Human Development in the Era of Industrial Revolution 4.0
}

\author{
Nurul Izmaliza Syakila Yahaya ${ }^{1}$, Nur Izzati Husna Sapian'1, Imran Syhami Abdul Razak¹, \\ Mohamad Izzuan Mohd Ishar ${ }^{2}$ \\ ${ }^{1}$ Fakulti Sains, Universiti Teknologi Malaysia (UTM) \\ ${ }^{2}$ Sekolah Pendidikan, Fakulti Sains Sosial dan Kemanusiaan, Universiti Teknologi Malaysia (UTM) \\ Correspondence: Nur Izzati Husna Sapian (zatyhusna99@gmail.com)
}

\begin{abstract}
The 4.0 Industrial Revolution and the Internet of Things (IoT) have been a hot topic over the last few years. The Industrial Revolution of 4.0 has brought a drastic change in various aspects of human life. With the growing demand for today's increasingly sophisticated technology in the era, it can bring a tremendous impact on the development of the community. One in five jobs will be replaced by artificial automation and intelligence (AI) within five years as an organization around the world focusing on the use of technology to improve efficiency in their business. New jobs will appear to balance and allow employees to perform higher tasks, which will lead to a restructuring role across the business. In recent years, there has been an increase in technology investment worldwide, and only awaiting robots and other cognitive technologies to work in the place where the development of the community is here encompassing the pros and cons of the technology to the public to achieve the 4.0 industrial Revolution in Malaysia. The development of technology resources nowadays has resulted in a high standard of innovations and creations that can bring the world to the new millennium. As such, the advanced Technology device equipment is now readily available anywhere. According to the official Portal of the National Archives of Malaysia in 2015, innovation in various sources of technology is produced to enable the Community's communication and the current human interaction is more quickly and able to exceed time and place. Due to the widespread use of each generation of advanced technology, it has led to the adoption of moral values and the development of one generation to another.
\end{abstract}

Keywords: industrial revolution 4.0, life development, technology

\section{Introduction}

Industrial Revolution 4.0 is a digital industrial revolution where it roughly combines traditional manufacturing technologies and processes involving the Internet of Things (IoT) or the material internet used in the daily lives of every human being. With the rapid development of technology that has undergone penetration in all areas, including the field of artificial intelligence, nanotechnology, biotechnology, internet-based technology has an impact on human life that can enhance economic growth. The impact of economic growth has increased in the industrial revolution 4.0 where this can be seen from many business people and entrepreneurs who take advantage of information technology so that the basic principles of industrial design 4.0 are known as the digital revolution due to the proliferation of computers and smart robots. 
The world is now heading into a new millennium, where the flow of technology is so sophisticated in line with the industrial revolution 4.0. Many countries are now turning their attention to technology by taking the opportunity to make the technology industry the engine of the country's economic growth. According to Read (1937), defining technology covers all the tools and machines that will be used by humans in increasing the productivity of an organization. In general, technology is defined as an application of scientific knowledge that can utilize and help solve human problems faced in daily life. The advancement of science and technology as the driver of the industrial revolution is also followed by other negative effects such as the reduction of manpower and requires high costs to create a product.

According to Prof Schawab (2017), he explained that the 4.0 industrial revolution has fundamentally changed the human life and work fundamentally. Technology devices have a lot of impact whether negative or positive on the community. The use of advanced technology in the current era has changed many ways of life in society in various aspects regardless of their age and degree. Children especially become one of the simple and easily influenced groups with advanced technology devices. As we know there are some drastic changes in terms of education and growth of children, economy, and health due to the existence of advanced technology in this century.

\section{Objectives}

This research aims to examine each of the impacts that occur on humans caused by technology:

i. To identify what technology is and its impact on humans from both positive and negative angles.

ii. To investigate how people are using technology that makes them become a technological addict.

iii. To examine the community's knowledge of the Industrial Revolution 4.0 that is taking place in Malaysia.

iv. To analyze the education system that occurs in Malaysia then and now.

v. To assess the responsibilities of parents to their children in this era of the Industrial Revolution 4.0

vi. To evaluate the importance of technology to modern human beings.

\section{Literature Review}

The life of a society that has been influenced by modern technology has led to a cultured process of society with the media where most aspects of culture and the application of values are passed down from one generation to another through media such as television, internet and so on. Sophisticated technology devices not only influence adolescents and adults but also these problems can affect the social development of children. Children nowadays have relied on technological devices for almost their entire daily activities. The social development of a family can also be affected by the temptation due to the use of advanced technology such as smartphones, surfing the internet, and social media. It can be said that there are also a handful of parents in the present era such as relinquishing the responsibility to spend time with their children on technological devices. They usually use this device to prevent the child from getting upset or crying. Here we can see that technological devices can help parents in managing their household affairs. However, the use of technological devices such as smartphones by minors can slow down their growth. This should be avoided by parents even though the world today has produced a variety of sophisticated devices that are increasingly stepping in line in line with the Industrial Revolution 4.0.

Not only is the role of parents but also family members also important to ensure the growth of children. According to Al Mazmi, Aslam, and Rajan (2013) technological devices are not only able to negatively impact children such as causing sleep disorders and insufficient sleep problems, poor 
language proficiency and lack of social skills including the inability to understand body language, causing malnutrition, etc. and even these devices are also able to have a positive impact on the progress of the Industrial Revolution 4.0 such as new equipment and effective medium for education, but the learning process can also be enhanced as these devices provide opportunities for self-learning, provide a solid foundation for planning and make encouraging improvements, etc. The technological devices in the current era that are increasingly achieving to go to the Industrial Revolution 4.0 not only provide opportunities but also get opposition from the people who step into adulthood who need jobs to make a living. This is because the existence of sophisticated technological devices has made it difficult for people like this to get a job. Industrial Revolution 4.0 has fundamentally changed human life and work (Prof Schawab, 2017). All disciplines of knowledge, economics, industry, and government have been influenced by the advancement of new technologies. Due to the production of advanced technological devices that are stepping into the Industrial Revolution 4.0 such as the existence of supercomputers and smart robots has caused less manpower is needed directly in a field. Intelligent machines and robots have dominated a field of work that human beings need to do. This has led to an increase in the unemployment rate in Malaysia because new graduates are not able to get jobs due to the existence of these state-of-the-art technology devices.

Employees also need to work overtime or outside working hours because the technological sophistication of creating information and communication technology (ICT) has caused employees to receive additional work from their employers via email, social media applications such as WhatsApp, and so on. This has led to conflicts between family and work. Before the advent of technology in ancient times, society was able to divide time wisely between work and family. But now we can see that there are also a handful of people who are not able to divide their time wisely and fairly because they are bound by the responsibility to work outside of working hours. The existence of state-of-theart technology has also had an impact on education. This is because technology has caused the percentage of teachers to be reduced. Teachers only need to mentor students physically. The rest, students can get all the shortcomings in learning through technological devices. This has made it difficult for new teacher graduates to get jobs and their unemployment rates are very high. As we have seen, many graduates involved have to wait for several years to get a job in education. This is because technology has dominated the education sector in the country. Everything is in the technological devices that are stepping into the Industrial Revolution 4.0. Students only need to be proficient in operating the devices.

However, the existence of technology in education can have a positive impact on students. Technology devices can be used as one of the ways to overcome the lack of an education system in the past era. Technology is also able to expose the students to study alone or in groups. They do not have to expect guidance from their teachers completely. They will also be exposed to state-of-the-art learning systems on par with foreign countries. This can produce many high-ranking graduates. Students are also able to deal with learning time without the time and place limitations because they only need to access it in the technological devices they have. Among the latest technologies that have been introduced are online open courses (MOOCs) and mixed learning tools (BL). MOOCs and BLs are now being applied by English teachers around the world to help teach them in the classroom. The integration between both face-to-face (offline) interactions and online materials has shown great potential for students as they find them useful (Bruff, Fisher, McEwen \& Smith, 2013). The emergence of these knowledge tools can be experienced in the context of Malaysian classrooms. For example, lecturers from Malaysian institutions have initiated the MOOC initiative (Fadzil, Abdol Latif \& Tengku Mohd Azzman Shariffadeen, 2015).

Entering the year 2020, most Malaysian institutions have now received many recent developments in the world of education to enrich teaching. Teaching and learning with ICT facilities will make teaching and learning more meaningful because teaching orientation is student-centered. Teachers act as facilitators and problem solvers. Johson (1986) explained that the use of ICT in teaching can be applied in all subject areas such as science, mathematics, language, and literature. Computer software helps students to think critically and produce meaningful learning not just presenting information from textbooks or other sources solely in the form of media. Technology devices are also able to impact the social change of society. Technology devices can be categorized as tools that must be owned by the 
community because through these devices they will get a variety of very important information related to current issues, sports, education, health, and entertainment. Besides, technological devices will also cause social, moral, political, and economic problems. The power of technological devices can have a huge impact on the lives of people. To move in line with the Industrial Revolution 4.0, society needs to expose itself to the use of state-of-the-art technology. But, the attitude of a handful of people who take advantage of the technology industry has caused misunderstandings in life. Technology devices are very suitable for the development of community life but the way they use them will cause a problem.

The advent of state-of-the-art technology has brought society out of the cocoon of an outdated life. The public will receive current news easily and quickly no matter inside or outside the country. Technology is also able to form a harmonious society. This is because the use of technology will lead the community to interact bilaterally with other communities. The prudent use of technology is important so that there are no problems between communities. The development of technological currents in line with the Industrial Revolution 4.0 can have a negative and positive impact both. This greatly affects the community, especially in terms of employment and a harmonious environment. The widespread use of technology has affected the domestic labor sector. This problem has had a huge impact on the workers out there. The use of technology for children needs to be carefully monitored. These state-of-the-art devices can have a very negative impact on their growth. What is the point of producing sophisticated devices but the growth of alpha generation children will be affected. The birth of heirs who can think openly and towards excellence and count towards the future will also be affected. However, the use of technology in the education system is very necessary for the birth of intelligent people. Such people are very much needed to ensure the future of the country. Hopefully, the production of increasingly sophisticated technology in the future can have a very high positive impact on the negative impact on the life of society.

\section{Methodology}

In a study or research conducted, it requires an effective method or method to obtain information on the findings of the study. By obtaining sufficient data and information, only then can a study be conducted well. A library study has been conducted to complete and complete this study. We have used sources of printed materials such as reference books, newspapers, and magazines as well as electronic materials as well as reliable sources from the internet. We have read many articles related to the title of the study. By reading many books and articles, we have obtained more sources of information as well as additional information that can be used as input material to complete this study. For this purpose, we have obtained printed reference sources such as reference books and past studies in several libraries, such as Sultanah Zanariah Library and Raja Zarith Sofiah Library. We have also obtained and analyzed many articles and theses that have been done by those who are trustworthy.

Apart from library research methods, we also use observation methods in obtaining information and sources of information. To obtain this information, we observe the actions and behaviors of parents in controlling the situation with their child. In addition to parents, we also observe the behavior of students in their educational aspects. By using the technology provided, students are free to do anything and do not have to ask for help from others anymore. We also used the questionnaire method. The use of this method has enabled us to know the extent to which advanced technology has impacted society in this era of Industrial Revolution 4.0. We are also able to know the real problems faced by society in the current era of technological sophistication. By using some of the specified methods or methods, we hope that this study can follow its standards and quality. The methodology of this study also aims to facilitate us to obtain data and information from observations and respondents of the study. It is considered as a guide for us in producing and completing this study. 


\section{Research Analysis}

Percentage descriptive analysis is used to collect the percentage of public opinion agreement on the questions posed. 12 questions have been asked to the community. Technological advances are inseparable from humans. However, there are many positive and negative impacts on all walks of life. Referring to the first and second questions, parents in this era are still relinquishing their responsibility to children to technological devices. As a result of the study, children aged 7 years and below have been exposed to technological devices such as smartphones, tablets, and computers. Exposure of technology to children with the consent and consent of their parents to calm the children when shopping or when out of the house. Parents also allow their children to use technology because parents have more important work at home and do not care about their children. Children have also used this technological tool on a daily or regular basis. However, some parents believe that the use of touchscreen technology has a positive and negative impact on the intellectual and physical development of children. Also, Vittrup et al. (2016) have conducted a study on the use of technology among children in the United States. The objective of this study was to examine the attitudes and perceptions of parents on children's technological knowledge to identify the child's real knowledge and experience of the use of technological tools. The results of the study have shown that most children have personal access to various types of technology.

Table 1: Attitudes and perceptions of parents on children's technological knowledge

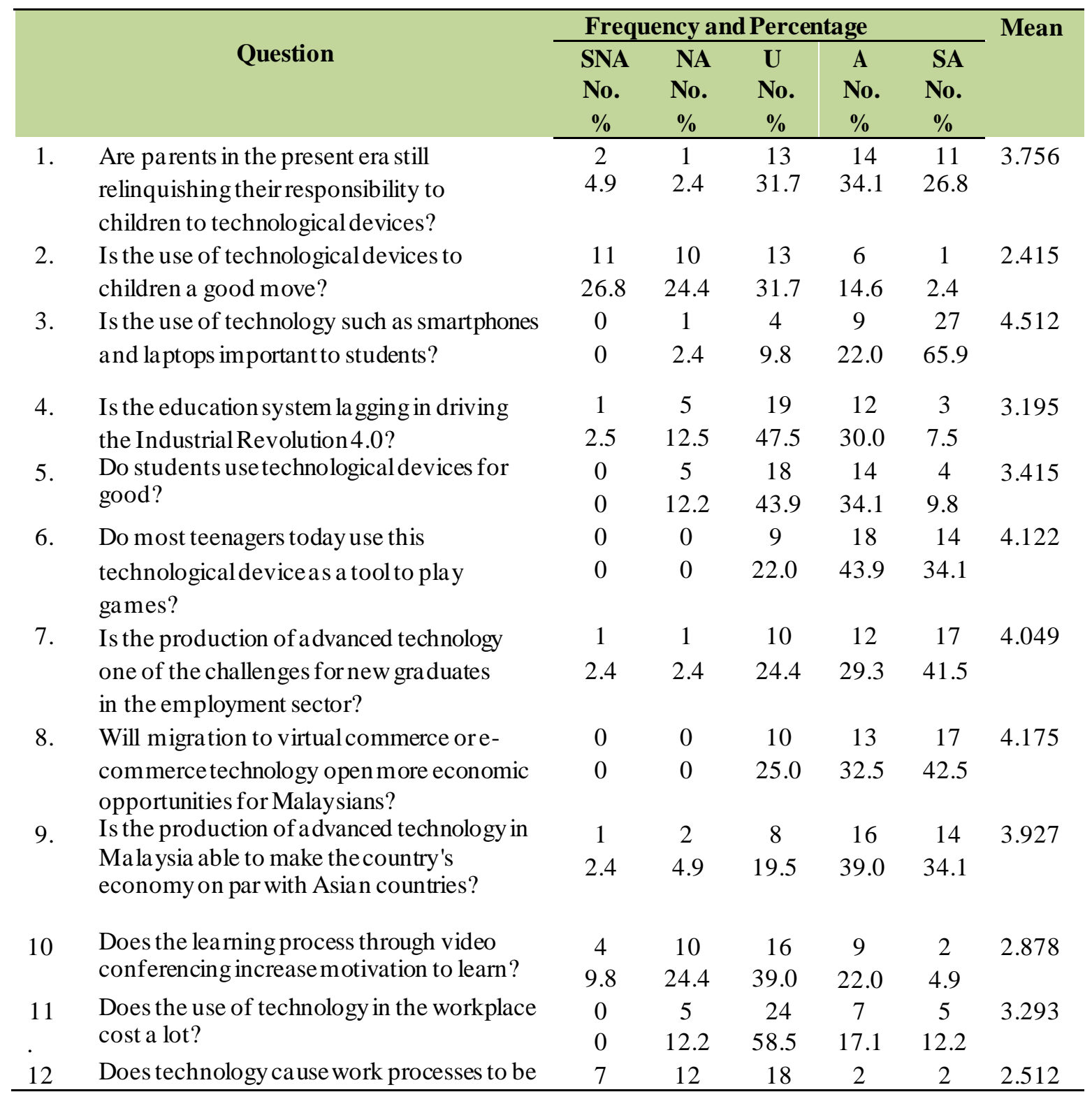


Vittrup et al. (2016) have found that television is a technology that is often exposed to children at home with an average of almost 3 hours a day on average. Due to parental behavior, the average child has a high level of knowledge of technological devices such as mobile phones, digital cameras, video games. This is also supported by parents who think that children have been exposed to the use of technology no matter where they are either at school or home since they are young. The study also proves that parents use technology such as television, computers, video games, and mobile phones for almost 7 hours every day (outside of working hours). This is one of the biggest factors that make children too vulnerable to technological gadgets. Parents' perceptions of technology influence the exposure of technology to children. Parents think that the use of technology can help the development of children but instead also bring unwanted effects and risks to them. Therefore, the use of this technology gadget is indeed beneficial but the role of parents in monitoring the movement and controlling the use of children's technology should be emphasized. Parents also need to set a good example so as not to be a role model for children because parents are role models for children.

Referring to the third question, the use of technology such as smartphones and laptops is very important to students. In Malaysia, mobile learning is one of the rapidly growing learning mediums in line with the era of technological modernization. The teaching and learning process in schools and universities nowadays is no longer concentrated in the classroom alone, instead, it can happen anywhere and anytime. Mobile learning is a learning approach that determines the level of mastery, knowledge, and skills through increasingly advanced mobile technology in the country. Mobile communication technology has provided various alternatives and facilities to communicate with fellow human beings. For example, mobile phones are no longer limited to receive and make calls just like in the past. Nowadays, a mobile phone can receive and send SMS as well as can access many useful applications.

Besides, by using mobile phones users can also browse websites and browse various applications that can benefit a person. Users can use applications that require internet access anywhere with wireless communication facilities. By using a mobile phone or laptop, students can share notes with other students without a time limit. The broadband or WiFi service provided by the subscribed mobile phone service provider has made it easier to share the notes and download the notes. In the era of technological advancement as well, most teachers and lecturers will do online classes. This will make it easier for a person to learn no matter where they are. The use of technology in educational institutions should not be subject to limits or barriers that can impede one's teaching and learning process. By using existing technology tools, students can do online learning such as electronic learning (E-Learning) has been further expanded through M-Learning. Overall, with the advent of technology devices such as smartphones and laptops indirectly have the opportunity to change the form of learning methods to create a broad and effective learning community that can connect people in a realtime or virtual world.

Referring to the fourth and fifth questions, the education system in Malaysia is not lagging in driving the Industrial Revolution 4.0. Most educational courses in schools and universities that create job opportunities are never outdated but the way of delivery and teaching is no longer suitable for the era of the new industrial revolution, the Industrial Revolution 4.0. According to the Minister of Education Malaysia (2018), no field of knowledge is outdated but the way of teaching may no longer be effective with the existence of new technologies that are the lifestyle of the current generation. According to him, with the use of smartphones that fill the living space of the community, the way of studying at the university which involves long lecture sessions is considered inappropriate. The education system in schools and universities has now begun to move towards digital-driven learning that is more interactive and flexible. The current learning methods in Malaysia that require us to be in the lecture hall while copying notes from the blackboard may be a bit behind, he said. By holding smart classrooms at the primary and secondary school levels has made the learning system more flexible and interactive. At the same time, those responsible for the education system are also actively introducing new courses based on creativity in line with the Industrial Revolution 4.0. The Industrial Revolution 
began with water, steam, and mechanical power followed by electricity and later the birth of computing, automation, and electronics.

This Industrial Revolution 4.0 refers to intelligent machines or robots connected to internet access to technological systems that can visualize the entire production chain and make their own decisions without the need for many employees. It represents a combination of the cyber-physical system, Internet of Things (IoT), or material internet and is based on internet networks. Individuals among young people need to be prepared in advance for speculation about employment conditions adopting IR 4.0 worldwide. Sijil Pelajaran Malaysia (SPM) graduates who want to continue their studies need to be prepared and know that future employees not only need them to learn various information and new knowledge but also need to be combined with wisdom to optimize the information and knowledge they have to get a job. To continue to be the creator of a growing workforce in line with the industrial revolution, the Ministry of Higher Education has laid the right foundation to ensure the survival of higher education institutions (IPT) in Malaysia. Apart from that, the education system in Malaysia is also proactive. The change in the education system implemented is to use the latest technology and include aspects of learning space, teaching methods, a curriculum that is more organic and flexible. Students not only need to be smart to get information to support the development of their knowledge but also need the wisdom to optimize the knowledge they have for the sake of existing technological advances.

Next, referring to the sixth question, it is undeniable that today's teenagers and children use their technological devices as tools for playing games. Video games are already ingrained in a person's life, especially among children as well as being their loyal friends. There are many disadvantages that a person will face if he regularly plays games. One of them is the presence of addiction in a person. Every computer game has its appeal so that it can be addictive to anyone who tries it for the first time. When this persists, teenagers, especially students, will spend more time on computer games than reviewing lessons. This will cause their studies to be neglected and cause their academic performance to decline. The World Health Organization (WHO) has stated that online game addiction or game disorder in the latest version of the International Statistical Classification of Diseases (ICD) is defined as a mental disorder. Also, teenagers who like to play computer games suffer from a lack of soft skills such as social skills, communication with the community, and most importantly the skills in adapting to the environment. This will have an impact on the identity of the teenagers themselves where they will feel depressed and humble when faced with the surrounding community. Excessive play can have a detrimental effect on one's health. This is because they spend more of their time playing virtual games instead of having some physical exercise. Continuous glare from the screen can also damage a person's vision for a long time. The effect of video games on children is the occurrence of aggressive behavior. Negative influences when playing video games are often associated with the type of game and the value of violence found in the video game.

According to Ballard and Wiest (1996), the more the value of violence is found in a game, the more it has the potential to produce negative influences such as aggressive behavior on the game. Rodasta, Malouff, and Schutte say that children who play environmentally friendly games prefer forest-type games compared to children who play violent games such as characters that are games in the form of fights or wars are more likely to show aggressive behavior during play (Dayne Trikora Wardhani, Adi Fahrudin, 2010). Besides, children will suffer from obesity such as obesity and high blood pressure. According to Tazawa (2015) has found that children who play video games for a long time of more than five hours a day will suffer from disease syndromes such as headaches, nausea, chest pain, and can contribute to obesity (Craig A. Anderson, Nobuko Ihori, Brad J. Bushman, Hannah R. Rothstein, Akiko Shibuya, Edward L. Swing, Akira Sakamoto, Muniba Saleem, 2010). . The cause of obesity is due to their unhealthy lifestyle. Also, children will experience sleep disorders that affect the body's metabolic system so that they become often tired. They will also suffer from diseases such as heart rate and high blood pressure (Ballard and Wiest, 1996).

Next, referring to the seventh question, most respondents have agreed that the production of advanced technology becomes one of the challenges for new graduates in the employment sector. This is because, in line with the Industrial Revolution 4.0 which is generally the beginning of a new era with 
the emergence of advanced technology, namely smart robots and supercomputers. With the production of smart and sophisticated technology, this shows the technological capabilities without directly involving manpower in a particular field, task, or job. Many new graduates out there are looking forward to a job after successfully graduating. But it is not as easy as one might think. The use and application of sophisticated and intelligent technology are gaining attention and attraction in a work organization today. Such attention and attraction has indeed led to the progress and increased productivity of an organization.

However, this development has led to a reduction in the workforce or civil servants as well as the private sector in an organization as referring to eighth and ninth questions. This has indirectly increased the unemployment rate for new graduates. This is one of the challenges for them. With the existence of various sophisticated machines and smart robots in line with the development of technology can complete various types of jobs in a short period without handling or assistance from many employees. The work that should be done by humans has been taken over by smart machines and robots so that many workers are facing layoffs and reductions in every department and organization. The rapid development of technology has led to significant changes to the current employment pattern as many jobs in the past have now been eliminated. For example, the work of typists in the past done by manpower is now extinct due to the rapid advancement of technology used in today's field of work. Besides, employees at counters such as banks are also reduced with the existence of online systems and automatic teller machines (ATMs and deposits).

Finally, advanced technology is constantly evolving. This causes the technology to need continuous improvement and in turn, it will cost a lot of money. Every update that occurs should be informed to employees through courses, workshops, or training. Therefore, it will take a long time. According to Belcher (2010), during this process, the productivity of the company will decrease as employees need time to adapt to the newly introduced system. Furthermore, the company must bear the cost of software, technical services, and the implementation of burdensome courses. Every improvement in technology or system that is done will also cause the motivation of employees to decrease as they must face difficulties to learn new applications and achieve new standards. Continuous maintenance fees had to be borne by the company after all system upgrade work was completed. Also, cost savings will not occur if employees use the facilities of machines, computers, the internet extensively. For example, the use of computers and the internet is used for too long to increase the payment of electricity bills in addition to having to pay for the internet facilities used. The purchase of machinery and other technologies also costs so much that the company has to make payments in installments for several years to pay off the entire cost.

\section{Conclusion}

In conclusion, the current development can produce a significant impact on the life of society, including the current pattern of employment. This impact we can all feel when the pattern of employment that has long been practiced in society is now changing little by little with the development of technology and then we also have to face various negative impacts due to this phenomenon. Machines only need to do what a human being cannot do (Jack Ma, 2000). Only in this way do we could make machines as partners working with humans, rather than being a substitute for humans. Hopefully, technological advancement in the future can bring many benefits, especially in the employment sector so that the negative effects of the use of technology in the employment sector can be minimized (Zulkifli, 2011). Besides, some students or children show a positive attitude or high interest in the use of technological devices in their daily lives is due to the attractiveness found in such technological devices such as various applications, entertainment, games, and so on. However, there are negative effects that will occur on children are also undeniable so that can cause a sense of addiction or obsession in them. This in turn will give harm the social development of students if not controlled in the early stages of childhood. Next, the caregiver is the individual closest to the child or student. They need to play an important role in maintaining and monitoring the use of technological devices such as mobile phones or laptops so that their obsession or socio-negative emotional formation does not reach a critical level. 


\section{References}

Ahmad Fauzi, M. A., Norhasni, Z.A., \& Andi, S. (2014). Hubungan Antara Penggunaan Internet Bermasalah Umum dan Kesunyian Dalam Kalangan Pelajar Sekolah Menengah. Jurnal Kajian Pendidikan, 4(2), 189-200.

Badlishah Ahmad, R. (2019). Bangkit Bersama Negara Hadapi Cabaran IR 4.0. 3 September 2015. Berita Harian Online. Retrieved: https://www.bharian.com.my/rencana/muka10/2019/09/602995 /bangkit-bersama-negara-hadapi-cabaran-ir-40

Gusmaneli (2012). Dampak Teknologi Pendidikan Terhadap Peranan Guru di Masa Depan. Jurnal AlTa'lim, 1(2), 166-172.

Naquiah, N., Sahrunizam, S., Dharsigah, B.S., Nurhidayu, R., \& Abdul Hafiz, A. (2018). Impak Negatif Teknologi Moden Dalam Kehidupan dan Perkembangan Kanak-Kanak Hingga Usia Remaja. UMRAN International Journal of Islamic dan Civilizational Studies, 5(1), 87-99.

Nur Aisyah, K. (2019). Kesan Negatif Teknologi. Technical Report. Universiti Malaysia Sabah.

Salmah, O. \& Malisah, K. (2015). Pengaruh Peranti Teknologi Kepada Perkembangan Sosial dan Permasalahn Kesihatan Kanak-Kanak. Jabatan Sains Sosial, Fakulti Sains Pertaniaan dan Makanan: 1-11. Universiti Putra Malaysia Kmapus Bintulu.

Sohana, A.H. (2016). Pengaruh Media Massa Terhadap Perubahan Sosial Masyrakat. Journal of Social Sciences and Humanities, 1, 214-226.

Swamenathan, M. (2014). Dunia Digital: Kebaikkan dan Keburukkan Terhadap Perkembangan Kanak-kanak. 8 Oktober 2014. Pengasuhan Positif. Retrieved: https://mypositiveparenting.org/ms /2014/10/08/dunia-digital-kebaikan-dan-keburukan-terhadap-perkembangan-kanak-kanak/

UKEssays. (November 2018). The negative effects of technology. Retrieved: https://www.ukessays. 